\title{
Emerging Trends and Persistence of Inter-Ethnic Conflicts in Kenya
}

\author{
Rev. Julius Guantai Mwamba ${ }^{1}$, Dr. Dickson Nkonge Kagema ${ }^{2} \&$ Dr. Benjamin Mugambi Kanga ${ }^{3}$ \\ 1. PhD Candidate, Department of Humanities, Chuka University, Kenya. He is the Moderator of the \\ Presbyterian Church of East Africa. \\ 2. Department of Humanities, Chuka University, Kenya \\ 3. Department of Education, Chuka University, Kenya \\ Contact: Dr. Dickson Nkonge Kagema, Chuka University, P.O Box 109-60400 Chuka, Kenya
}

\begin{abstract}
Ethnic conflicts remain the biggest setback to the development of many African nations today, Kenya included. This study analysed the emerging trends and reasons for the persistence of inter-ethnic conflicts in Kenya. It was undertaken in the context of the Presbyterian Church of East Africa (PCEA) and was done in inter-ethnic prone Counties in Kenya including Nakuru, Eldoret, Laikipia and Mombasa. The study population was 1,624,345 PCEA members drawn from Nakuru west, Nakuru East, Njoro, Elburgon, Laikipia, Eldoret and Mombasa Presbyteries which are perceived as inter-ethnic conflicts dominant. A sample size of 384 respondents obtained through random sampling was selected from the presbyteries in the study locale. The study adopted a descriptive survey research design employing mixed methods of data collection. The instruments for data collection were questionnaires for the Church elders and members, structured interview guide for Church ministers and Focus Group Discussions (FGDs) for victims. The study established that the major reasons for the persistence of interethnic conflicts in Kenya are radicalization, economic imperialism, elite manipulation, deep-rooted cultural practices and language prejudices. These are the vices that must be eradicated if at all the inter-ethnic conflicts which have been the major hiccups to the socio-political and economic development of Kenya will be effectively addressed.
\end{abstract}

Key Words: Kenya; inter-ethnic conflicts, Presbyterian Church of East Africa

DOI: $10.7176 /$ RHSS/9-16-05

Publication date: August $31^{\text {st }} 2019$

\section{Introduction}

Since the end of the Cold War in 1980s, the world has witnessed an increasing number of inter-ethnic conflicts. In Africa, ethnic conflict is inherently a problem that requires effective peace building strategies to ensure ethnic tolerance and cohesion (Lynch, 2011). In Kenya, there has been a marked increase in ethnic conflicts in the recent times (Onyebadi \& Oyedeji, 2011). Since independence, Kenyan politics have been guided by ethnic politicking and competition, hence ethnic conflicts in 1992, 2002 and climaxed by the grave 2007/08 postelection violence which had a repugnant effect on this country. The conflicts in Kenya are multiple and overlapping resulting from a range of factors including ethnic intolerance; historical injustices; border conflicts; ethno-regionalist sentiments and political party zoning; radicalisation; competition over land and other resources; proliferation of small arms; weak security; poverty, underdevelopment, and marginalisation. Inter-communal violence risks being increased by competition over the fruits of devolution and elite manipulation of local communities (Ombaka, 2015; Dowd \& Raleigh, 2013; Halakhe, 2013; Sharamo, 2014; Boone, 2011).

It cannot be overemphasized that conflicts are the major hiccups to the development of Kenya and the rest of African countries since independence (Kagema, 2015, and any effort to develop Africa must aim at their eradication. This study employed the Liberal Peace Theory advanced by Lederach (1997), which advocates that the concept of peace building and reconciliation is understood as a process that takes place along approaches of conflict resolution. This is in line with Wafula (2014)'s view that reconciliation is a condition that goes beyond the conflict. Notably, the approach adopted in this study focuses on reconciliation as the last challenge to reach in order to sort out a conflict. As long as you have people previously confronted not reconciled, the conflict is still there and the violence is likely to flourish anytime. Liberal peace theory thus underscores that reconciliation is fundamental in conflictive contexts in order to get people living together in long term peace. Lederach (1997) lauds the expansion of conflict resolution to include alternative dispute resolution, mediation, conciliation, violence prevention, early warning systems, community reconciliation, nonviolent peacekeeping, trauma healing, second-track diplomacy, and problem-solving workshops. 


\section{Methodology}

This study adopted the descriptive survey research method employing a mixture of qualitative and quantitative methods in many phases in the research process. It was conducted using a qualitative, phenomenological indepth interview and conduct Focus Group Discussions to examine the dynamics of inter-ethnic conflicts in Kenya and reasons for the persistence of the inter-ethnic conflicts in this country. It was undertaken in the context of the Presbyterian Church of East Africa (PCEA) which Kagema (2012) informs that is among the fastest growing Churches in Kenya. Seven selected PCEA presbyteries located in Counties where inter-ethnic conflicts have been reported dominant namely Nakuru west, Nakuru East, Njoro, Elburgon, Eldoret, Laikipia and Mombasa were purposely selected for this study.

The target population was 1,624,345 PCEA members from the presbyteries chosen for this study namely Nakuru West, Nakuru East, Njoro, Elburgon, Eldoret, Laikipia and Pwani comprising of 103 ministers, 1620 church elders and 1, 622,622 Ordinary church members. The presbyteries were chosen because they are located in the conflict prone Counties namely Nakuru, Eldoret, Laikipia and Mombasa. This is reflected in Makori (2011)'s Report on Ethnic Conflict and National Security in Kenya, which showed that that Nakuru, Eldoret, Laikipia and Mombasa are the worst hit Counties by conflicts in Kenya. Table 1 below shows the distribution of the presbyteries in the study locale and their population according to Church records of the year 2018. Using Kathuri and Pals (1993)'s table, 384 respondents were selected for this study. Out of the 384 respondents, there were 7 Church ministers, 38 Church elders and 342 Church members who were affected by ethnic the conflicts. Simple Random Sampling was employed to identify the respondents.

Table 1

Distribution of the Study Population

\begin{tabular}{lcccc}
\hline Presbytery & $\begin{array}{c}\text { Population of } \\
\text { Church Ministers }\end{array}$ & $\begin{array}{c}\text { Population of } \\
\text { Church Elders }\end{array}$ & $\begin{array}{c}\text { Population of } \\
\text { Church members }\end{array}$ & Total \\
\hline Nakuru West & 15 & 272 & 607000 & 607287 \\
Nakuru East & 19 & 284 & 636000 & 636303 \\
Elburgon & 10 & 202 & 155000 & 155212 \\
Njoro & 13 & 242 & 202000 & 202255 \\
Eldoret & 10 & 150 & 3770 & 3930 \\
Laikipia & 26 & 290 & 9011 & 9327 \\
Pwani & 10 & 180 & 9841 & 10031 \\
Total & 103 & 1620 & 1,622622 & 1624345 \\
\hline
\end{tabular}

Source: PCEA Records, 2018

\section{Findings}

\subsection{Reasons for Persistence of Inter-Ethnic Conflicts in Kenya}

38 PCEA elders and 342 ordinary church members provided with reasons they perceived as the cause of the persistence of ethnic conflicts in Kenya. Using a likert scale, they were required to indicate level of agreement with the reasons that were suggested by the researchers. The responses were measured on a five-point Likert rating scale provided, including 'strongly agree' (scored 5), 'agree' (scored 4), 'neutral' or 'non-committal' (scored 3), 'disagree' (scored 2) and 'strongly disagree' (scored 1).

This section presents the available quantitative data which provides an overview of reasons for the trends in the persistence of inter-ethnic conflict in Kenya. This is followed by detailed information on some of the specific reasons which the study participants saw as important, their dynamics and specific contributory factors as revealed by the qualitative component of the research and supplemented by secondary data. The quantitative data obtained from questionnaires is captured in Table 2 below. 
Table 2.

Reasons for the Persistence of Inter-Ethnic Conflict in Kenya

\begin{tabular}{lcccccc}
\hline Reasons for Persistence of Inter-Ethnic & \multicolumn{7}{c}{ Responses $(\mathrm{n}=350)$} \\
\cline { 2 - 6 } Conflict in Kenya & $\mathrm{SA}$ & $\mathrm{A}$ & $\mathrm{N}$ & $\mathrm{D}$ & $\mathrm{SD}$ & Mean \\
\hline Radicalization & $190(54)$ & $122(35)$ & $22(6)$ & $4(1)$ & $12(3)$ & 4.35 \\
Economic imperialism & $204(58)$ & $94(27)$ & $12(3)$ & $16(5)$ & $24(6)$ & 4.25 \\
Exclusion and marginalization & $188(54)$ & $92(26)$ & $14(4)$ & $29(8)$ & $27(8)$ & 4.10 \\
& & & & & & \\
Elite manipulation & $192(55)$ & $122(35)$ & $11(31)$ & $9(3)$ & $34(10)$ & 4.38 \\
Deep rooted cultural practices & $178(51)$ & $132(38)$ & $3(1)$ & $24(7)$ & $13(4)$ & 4.25 \\
Language prejudice & $154(44)$ & $104(3)$ & $26(7)$ & $51(1)$ & $15(4)$ & 3.94 \\
\hline
\end{tabular}

From the results in Table 2, it is evident that economic imperialism (58\%), exclusion and elite manipulation (55\%), radicalization (54\%), Exclusion and marginalization (54\%), deep rooted cultural practices and stereotypes (51\%) and language prejudice (44\%) are main reasons for the persistence of inter-ethnic conflicts in Kenya. This implies that the majority of the Church elders and ordinary Church members see economic subjugation as the main reason for the persistence of inter-ethnic conflict in Kenya followed by elite manipulation, youth radicalization, exclusion and marginalization, deep-rooted cultural practices and finally language prejudices among others.

These are elaborated below.

\subsubsection{Economic Imperialism}

Findings of this study indicate that the majority of Church members generally agree that economic imperialism is one of the main reasons for the persistence of inter-ethnic conflicts in Kenya (This because 204(58\%) of the church members 'strongly agreed' and $94(27 \%)$ 'agreed, indicating that $85 \%$ saw economic imperialism as the real issue '). According to Mwadoe (2018), at the Kenyan coast, in Pwani presbytery, the indigenous groups complain of domination by "upcountry" communities in terms of economic opportunities. Indeed, such sentiments have often taken the form of calls for a neo-federal system of government at the Coast. Juma (2018) supported the views of Mwadoe by saying that Coast residents felt that all resources are concentrated upcountry and 'Pwani' or Coast is just a conduit.

This kind of scenario was confirmed in the Presbyteries. Following the interviews with 4 Church ministers and FGDs with 77 victims of inter-ethnic conflict comprising of 17 members in each group in Nakuru Presbytery and 60 in Eldoret Presbytery, the main contention is between the Kikuyu and the Kalenjin communities, where each community feels that the other denies it an opportunity to enjoy the county's economic benefits. According to the FGD conducted in Eldoret, the Kalenjins perceive the Kikuyu as crafty and opportunistic since they gradually occupied their land, established businesses and overpowered themselves economically in their own soil. Since the Kalenjins have been majorly pastoralists, they feel that the Kikuyus, mainly farmers, cheated them by buying their large tracts of productive land very cheaply and thus became too powerful economically (Kinyua, 2018). Therefore, the Kalenjins after realizing the value of land economically, have decided to fight "for their right", hence the persistence of conflicts despite many interventions. Thus issues such as corruption, poverty, inequality, Majimbo and economic growth have been reduced to a contest of ethnicities. For example, Corruption has been reduced into a "Kikuyu problem" where the Kikuyus are generally viewed as corrupt people. They are also viewed as the ones propagating 'inequality'. The reaction to this is 'Majimbo' where the Kalenjins have organized themselves so as reclaim their land (Cherono, 2018). This has been a source of conflict between these two communities living in Rift Valley (Kinyua, 2018). The responses of one of the respondents from Eldoret Presbytery can help us understand well how the situation is. She says that,

"The Kikuyus think that the Kalenjins are too foolish and therefore do not know the value of land and, that is why they treat them as half-citizens. The enlightenment of the Kalenjins is the main reason for the persistence of conflicts between these two communities".

From the FGDs carried out in Nakuru Presbytery, which is predominantly Kikuyu, the Kikuyu respondents regarded the Kalenjins as 'lazy and non-industrious'. According to them, the conflicts arise and persist because the Kalenjins are jealous due to the progress of the Kikuyus. For example Maina (2018) argued that the Kalenjins envy the Kikuyus' property not realizing that they get such wealth though hard work and resilience. 
This clearly shows that as far as some Kenyans are thinking like this we have a real problem. The government, religious organizations and other stakeholders have a hefty task if they will deal with this problem of inter-ethnic conflicts which continue to derail the development of this country and Africa as a whole. There will be need to change the attitude of communities towards each other so that they live in harmony. It is an issue that must be tackled properly. $345(89.8 \%)$ of the respondents were of the view that the economic empowerment of the citizens by the County and National governments would play a great role in reconciling the infighting communities.

\subsubsection{Manipulation by the Elite}

$192(55 \%)$ respondents strongly agreed, and $122(35 \%)$ agreed that elite manipulation was responsible for interethnic conflicts in Kenya. Thus $90 \%$ of Church members saw it as a real issue. Focus Groups identified significant levels of elite manipulation of ethnic ideology for political survival in the advent of devolution. This means that elite manipulation emerged as one of the main reason for the persistence of inter-ethnic conflicts in Kenya. There is a general feeling that the elite minority are the ones who control power, wealth and influence.

A similar finding was reported by Sehrawat and Sharma (2018) who posit that the state is seen as a possession of the ruling elite while at the same time alienating those who do not belong to the ruling political parties and affiliated ethnicities. In the same breadth, Botha (2014) provides the argument that political entrepreneurs use ethnic affiliation and manipulate ethnic grievances as the basis for political mobilisation. Mbugua and Rwanda (2018) support this view by asserting that a significant number of youth from certain tribes feel alienated from the national and county government employments thus show growing animosity towards them, largely because the political elites in government undermine the rule of law, making youth more vulnerable to underemployment. Similar assertions were generated in an exclusive interview with Reverend Kimani (2018), the Minister of PCEA St. Ninian's, Nakuru who held the view that political elites incite ethnic violence for political gain.

Mbugua (2013) avers that the incentives for inter-ethnic conflict in terms of political gains are stronger than those for peace. The conflict is said to operate in a way that constantly undermines any positive institutional initiative that may try to amend the system or ameliorate the problem. Recent attempts to mitigate the use of 'negative ethnicity' by political elites through robust state and electoral institutions and trying to foster the emergence of cross-cutting issue based political coalitions have not succeeded in changing the status quo of ethnic politics. Thus, the role of political elite' in instigating inter-ethnic conflicts has increasingly come under scrutiny as an emerging trend. Mumbi (2013) found that the Kenyan political elites have over time institutionalized ethnic politics and have used simmering ethnic grievances relating to land and exclusion to instigate ethnic-based electoral violence.

The role of elite pacts has been cited as a major determinant of political stability in a country, particularly a democratizing one (Guarnizo, Portes\& Haller, 2003). On why some African countries have remained politically stable while others have been plagued by civil wars, Lindeman (2008) argues that the key causal factor is whether inclusive or exclusive elite bargains (pacts) are part of the political process. In other words, the levelling of inter-elite inequalities reduces the incentives for excluded political elites to instigate violent conflict. A similar view point is expressed by Orji (2010) who compared the 2007 elections in Nigeria and Kenya. Orji argues that the reason for the peaceful elections in Nigeria versus the violence in Kenya has been the informal powersharing agreement between the country's ethno-regional elites. Regardless of their origins, it is clear that economic discrimination has been a pathway manipulated by the political elites in Kenya. Therefore, the more intense and prevalent the economic discrimination and community balkanization of communities along these lines are, the more likely that affected groups will be mobilized to resist the demands. The resultant dispute is very likely to take on an ethnic dimension. This brings to the fore that if the issue of political elite manipulation of their co-ethnics remain unaddressed, historical narratives and grievances will continue to prevent social cohesion among communities in Kenya.

\subsubsection{Radicalization}

$190(54 \%)$ of the respondents strongly agreed and 122(35\%) agreed that radicalization especially for the youth in Pwani presbytery has exacerbated the problem of inter-ethnics conflict in the region. This implies that $89 \%$ of the citizens feel that in the coastal region of Kenya, conflicts are largely due to youth radicalization.

There are dramatic regional variations in the types, tactics and perpetrators of inter-ethnic conflicts in Kenya. The nature and extent of crime and violence in the country varies according to the setting, that is, urban or rural, and the prevailing conditions of an area. The information gained was maximized by the use of key informant interviews and FGDs with respondents expected to have a broad or specific understanding of the dynamics (context and reasons for 
persistence) of inter-ethnic conflict in Kenya. In Pwani Presbytery, 2 clergymen interviewed and 1 FGD comprising of 11 Church members of inter-ethnic conflict indicated that youth radicalization was an emerging trend responsible for persistence inter-ethnic conflicts in the region. This is in tandem with Dowd and Raleigh (2013) findings that youth radicalization has tended to be clustered in the North Eastern regions which borders Somalia, the Coast area in the south-east, and Nairobi.

Sentiments derived from 11 victims of inter-ethnic conflict in Pwani presbytery who participated in FGD indicated that the history of youth radicalization into violence or radicalization leading to terrorism is quite contemporary and a complex psychosocial process. In trying to further espouse the issue, Munyoroku (2018) identified a number of factors responsible for the rise in violent extremism in Kenya, including the spill over of ideology, fighters and resources from Al-Shabaab's occupation of Somalia, external actors who have exploited the instability in the porous coastal region (such as Salafi ideology and links with the Arab world), a burgeoning Muslim youth population, socio-economic disparities and lack of political representation as the main factors leading to radicalization.

In a similar vein, the results obtained from the FGD comprising of 11 members who were victims carried out in Pwani presbytery on the $27^{\text {th }}$ day of October, 2018 at PCEA St. Margaret Church revealed that there were crosscutting drivers of inter-ethnic conflicts mentioned repeatedly which included radicalization mainly caused by religious intolerance or indoctrination perpetuated mainly through 'Madrasas.

In support of Munyoroku and the sentiments of FGD, Mwandoe (2018) said that in Pwani Presbytery, the failure to address persistent land issues, engage with moderate local leaders and to establish the county government as a legitimate authority could be fuelling interreligious tensions, extremism and inter-ethnic conflict gravitated by the emerging trends of radicalization. In an exclusive interview, Mwandoe (2018) highlighted that over the last decade since 2010 many young men in Pwani presbytery have received training after being recruited by radical preachers to fight in Somalia for the Al-Shabaab. Mwandoe (2018) adds that when such youth return home, some of them still see themselves as pursuing Jihad, while others are disillusioned by the experience in Somalia. Mwandoe (2018) further posits that the majority of the youth especially the Muslims in the coastal region are increasingly vulnerable to radicalization efforts, which liken their ethnic, racial, and religious marginalization to the systematic discrimination of all Muslims worldwide.

This discourse has increasingly appealed to Kenyan Muslims in the Coast effectively expanding Al-Shabaab's recruitment beyond Somali borders. These findings indicate that inter-ethnic conflicts especially in the Kenyan Coast is as a result of youth radicalization rooted in religious intolerance or indoctrination perpetuated mainly through 'Madrasas' and the spillover of Al-Shabaab's ideology.

\subsubsection{Social Exclusion and Marginalization}

Exclusion and marginalization were cited as the other the main reasons for the persistence of inter-ethnic conflicts in Kenya. Of the respondents that took part in this study, 188(54\%) strongly agreed, while 92(26\%) agreed that inter-ethnic conflicts that sporadically flare-up in Kenya were as a result of exclusion and marginalization. A Focus Group Discussion involving 17 people conducted at PCEA Saint Margaret Church in Pwani Presbytery revealed the history of exclusion and marginalization of coastal people. Goldsmith (2009) describes it as the "crisis of second-class citizenship", where the mixed-heritage Swahili are largely peripheral in post-independence Kenya.

The Coastal residents, according to the FGD members who took part in the survey, felt that exclusion and marginalization compelled them to the point of feeling that they were not Kenyans. Hence the slogan 'Pwani si Kenya' (Coast is not Kenya) based on secessionist tendencies. According to Nthambiri (2018), the Coast region has a long history of calling for secession from Kenya based on distinct ethno-regional identities and claims of socio-economic marginalisation of the region. These claims of socio-economic marginalisation are of particular concern where they overlap with religious narratives used by the Muslim militants in the volatile regions.

On his part Munyoroku (2018), posits that the violence in the Coast is characterised by 'relatively high volatility, reflected in sporadic spikes in violence, followed by relative lulls'. He asserts that until recently, street protests were the most common form of political action at the coast. Since 2008, the Mombasa Republican Council has regained momentum in its calls for secession, with a focus on land issues and economic frustration. Muthomi (2018) opines that people living in individual competitive conditions perceive ethnic out-groups as a threat, and that this in turn reinforces ethnic exclusionism. Contextual competitive conditions, particularly the presence of non-coastal citizens, also affect ethnic exclusionism. Muthomi (2018) further observes that there are close links between social exclusion and violent conflict and insecurity, both in terms of causes and consequences. There 
are now convincing arguments that some forms of social exclusion generate the conditions in which conflict can arise. This can range from civil unrest to violent armed conflict and terrorist activity. Severely disadvantaged groups with shared characteristics (such as ethnicity or religion) may resort to violent conflicts in order to claim their rights and redress inequalities. Group differences are not enough in themselves to cause conflict, but social exclusion and horizontal inequalities provide fertile ground for violent mobilization as has happened in the Kenyan Coast.

By analyzing why some societies with sharp horizontal inequalities suffer conflict and others do not, it became evident from the FGDs that conflict occurs most frequently when socio-economic and political horizontal inequalities are combined. While coastal communities have always nurtured the desire to exert sovereignty over their own affairs, land, and resources, the rise of the Mombasa Republican Council over the past years has imbued the issue with a renewed vibrancy and purpose (Nthambiri,2018).

\subsubsection{Deep Rooted Cultural Practices and stereotyping others}

$178(51 \%)$ respondents strongly agreed, and 132(38\%) agreed that deep rooted cultural practices and stereotypying were among the reasons why inter-ethnic conflicts continue to be experienced in Kenya. This implies that up to $89 \%$ of Kenyans see it as an issue. These findings agree with Wa Mutua (2017) assertion that inter-ethnic conflicts in Kenya are largely precipitated by deep rooted cultural practices such as male circumcision.

A Kalenjin Church elder, Sawe (2018) said that the Kalenjins have a deep cultural practice where young men are trained to fight and even kill. She explained that young men are cultured to be war-like and whenever an opportunity for war arises they are quick to seize it. She elucidated that most of the reasons being given by the Kalenjins as the reasons for persistence of conflicts are just triggers. The real issue is that the community is ready for war any time. She emphasized that political incitement, land issues and economic dominance just give the young men an opportunity to do what they are socialized to. In Laikipia Presbytery, the 13 member FGD revealed that the Pokot raid other communities not just for economic gain but the vice is deeply rooted in their culture. One respondent claimed that raiding is taken as a sport. This makes inter-ethnic harmony very difficult to achieve because some communities engage in battle as part of their normal life.

Other than the cultural aspect, communities living together stereotype each other so negatively that the generations that follow take the stereotypes to be factual. Different communities have a tendency of negative perceptions against each other. Ethnic stereotypes in Kenya are a major cause of ethnic tension that has led to bloodshed and displacement for many years in the county (TJRC, 2008). The FGDs in all the Presbyteries showed that stereotyping is a major reason for the persistence of conflicts in Kenya. In Pwani, Nakuru and Eldoret Presbyteries, the Kikuyus are stereotyped by all the other tribes as thieves, opportunists and land grabbers, people who love money excessively. This came out in all the FGDs and interviews and was cited as a reason as to why conflicts persist in Kenya. On the other hand, the Kikuyus regard the Coastal people and Kalenjins as lazy, non-industrious and envious; just waiting for hand outs. According to FGDs carried out in Eldoret Presbytery, the Kikuyus stereotype the Kalenjins as war-mongers; people who fight for no apparent reason and are ready for a fight all the time. The FGDs carried out in Laikipia Presbytery revealed that the Kikuyu, Maasai and Turkana communities regard the Samburus and the Porkots as cattle rustlers thus making the pursuit of inter-ethnic harmony very difficult. As far as these cultural practices and stereotyping are not carefully addressed peace and reconciliation remain a nightmare in Kenya.

\subsubsection{Language Prejudice and Stereotyping}

The results of this study indicate that 154(44\%) strongly agreed and 104(30\%) agreed that language prejudice is a trigger of inter-ethnic conflicts in Kenya. This implies that up to $74 \%$ of Kenyans see this as factor leading to inter-ethnic conflicts. Similar findings were obtained by Sharamo (2014) when he found out that when a group insists on using their language in a cosmopolitan set-up, the rest who are not privy to the language feel excluded and this may occasion flare-ups.

The 60 respondents who met at Ayub- Kinyua Church in Sirikwa, Eldoret town cited language choices in Church, business and general interactions in society as responsible for inter-ethnic conflicts among the various groups that lives in Eldoret. The main contention, they said, has been between the speakers of Kikuyu and Kalenjin languages. Though they cited other causes of conflicts for instance, the land issues and political incitements, they were emphatic of the fact that the insistence of the Kikuyus to use their language in complete disregard of others who cannot understand Kikuyu fuels animosity and makes it difficult for the stakeholders to 
address issues of inter-ethnic conflict. For example, the use of Kikuyu language in the Churches in total disregard of the presence of other communities was cited as a bad thing. The Kalenjins indicated that the predominant use of Kikuyu dialect in the Church Service makes them feel left out and makes the case for peace difficult.

The FGDs at Eldoret revealed that the trend of the Kikuyus, whom the Kajenjins view as intruders, changing the names of the indigenous Kalenjin places giving them Kikuyu names make the Kikuyus living in such places an easy target. For example, the Kiambaa PAG Church in Eldoret which was burnt and 35 people had taken refuge there killed during the 2007/2008 Post-election violence was targeted for this reason. The Church was originally called Lankia in Kalenjin language but the Kikuyus changed it to Kiambaa (Kikuyu language). Such others include PCEA Ayub Kinyua Memorial Church which was originally supposed to be Sirikwa among many others. The foregoing has made peace building efforts difficult in many parts of Rift Valley. It was because this that as noted by Ruto (2018), during the 2007/08Post-election violence most people took refuge in Catholic and African Inland Churches because they had retained the indigenous Kajenjin names. As such they were spared.

Notably, this problem is not a recent one. The reaction of the Kalenjins over what they consider the reclaiming of their ancestral land is not a new phenomenon, neither does it have its roots in the 1991/1992 ethnic clashes as it has been perceived by some people (See Githiga, 2001). As far back as 1969, the Honorable Jean Marie Seroney, who was Member of Parliament for Tinderet Constituency had drawn a controversy when he authored 'The Nandi Declaration' that demanded all non-Nandi residents vacate the ancestral land of Nandi. The Kenyatta government reacted by imprisoning Seroney for sedition but his ideas did not die. Ironically, in 1991/1992 President Moi's government adopted Seroney's template for ethnic exclusivity. He expanded to the larger Kalenjin community by evicting the Kikuyus, Luos, Luhyas and Kisiis in his bid to secure political victory in the Rift Valley. The truth is that despite public claims of reconciliation, divisions still run deep between communities in Rift Valley. As Rev. Maritim Rirei of the Anglican Church of Kenya, Eldoret Diocese puts it "The truth is that we are not making headway towards reconciliation (Rirei, 2018). These are issues that we will have to wrestle with if at all any meaningful reconciliation will be achieved in Kenya.

\section{Conclusion}

The dynamics of the inter-ethnic conflicts in Kenya are complex and intricate. While the Government, Church, Non-Governmental Organizations and other Peace agencies have made strenuous effort to bring forth Peace, Justice and Reconciliation in Kenya, their effort have been thwarted by the continuous persistence of inter-ethnic conflicts. The factors leading to this are many as we have discussed in this paper. It is imperative that we look at ways of addressing the issues raised including Economic subjugation, Manipulation by the elite, Radicalization, Social exclusion and marginalization, outdated cultural practices and language prejudice. Unless well tackled, these vices will continue to hamper the effort to bring justice, peace and reconciliation in Kenya. We are not saying that all is lost. What we are emphasizing is that all stakeholders must join hands together so that together we can build a stable country devoid of endless inter-conflicts which only derail the development of our country.

\section{References}

Ager, A. \& Strang, A. (2008). Understanding integration: A conceptual framework. Journal of refugee studies, 21(2), 166-191.

Anderson, D. \&Lochery, E. (2008). Violence and exodus in Kenya's Rift Valley, 2008: predictable and preventable? Journal of Eastern African Studies, 2(2), 328-343.

Augsburger, D. W. (1992). Conflict Mediation Across Cultures: Pathways and patterns. Westminster John Knox Press.

Bandyopadhyay, S., \& Green, E. (2013). Nation-building and conflict in modern Africa. World Development, 45, 108-118.

Boone, C. (2011). Politically allocated land rights and the geography of electoral violence: The case of Kenya in the 1990s. Comparative Political Studies, 44(10), 1311-1342.

Borum, R. (2011). Radicalization into violent extremism I: A review of social science theories. Journal of Strategic Security, 4(4), 2.

Botha, A. (2013). Assessing the Vulnerability of Kenyan Youths to Radicalisation and Extremism. Institute for Security Studies Papers, 2013(245), 28.

Branch, D. (2011). Kenya: Between Hope and Despair, 1963-2010. New Haven, Connecticut: Yale University Press.

Carbaugh, D. (Ed.). (2013). Cultural Communication and Intercultural Contact. London: Routledge.

Cherono, M (2018). Oral Interview at Eldoret on $17^{\text {th }}$ December 
Galanter, M., Dermatis, H., Bunt, G., Williams, C., Trujillo, M., \& Steinke, P. (2007). Assessment of spirituality and its relevance to addiction treatment. Journal of Substance Abuse Treatment, 33(3), 257-264.

Gerdes, K.E., Jackson, K.F., Mullins, J.L. \& Segal, E.A., 2011, 'Teaching empathy: A framework rooted in social cognitive neuroscience and social justice', Journal of Social Work Education 47(1), 109-131.

Gichimu, W. (2018). Reverend of PCEA, Interviewed on December $17^{\text {th }} 2018$ at PCEA Ayub Kinyua, Eldoret

Githiga, G (2001). Githiga, G. (2001). The Church as the Bulwark against Authoritarianism. Oxford: Regnum.

Jeni, K., Bilin, N., \& Frances, S. (1999). Development Centre Studies Conflict and Growth in Africa Kenya, Tanzania and Uganda Volume 2: Kenya, Tanzania and Uganda (Vol. 2). OECD Publishing.

Kagema, D. N. (2012). Developing church leaders in Africa for reliable leadership: A Kenyan perspective. Dutch Reformed Theological Journal= NederduitseGereformeerdeTeologieseTydskrif, 53(3 4), 229-240.

Kagema, N. D. (2013). The use of gospel hip-hop music as an avenue of evangelizing the youth in Kenya today: A practical approach. American International Journal of Contemporary Research, 8, 161-169.

Kagema, D.N (2015). The Role of the African Traditional Religion in the promotion of Justice, Peace and Reconciliation in Africa. International Journal of African and Asian Studies, Vol.15, 1-9.

Kaimba, G. K., Bernard, K. N., \& Abdi, Y. G. (2011). Effects of cattle rustling and household characteristics on migration decisions and herd size amongst pastoralists in Baringo District, Kenya."Pastoralism: Research, Policy and Practice 1(1): 1.

Kamwesiga, P. K. (2016). Small arms proliferation and homegrown terrorism in the Great Lakes region: Uganda's experience. Naval Postgraduate School Monterey United States.

Kariuki, J. K. (2016). Peace Building among the Urban Poor of Mathare Informal Settlement in Nairobi County: The Interventions of the Anglican Church of Kenya, Diocese of Nairobi 1999-2009. A Master of Arts (Religious Studies) Of Kenyatta University.

Kathuri, N. J., \& Pals, D. A. (1993). Introduction to Educational Research. Njoro Kenya.

Kebenei, R. (2018). PCEA Church Elder, Interviewed on December $18^{\text {th }} 2018$ at PCEA PCEAMuruai Church, Laikipia.

Kimani, M. (2018). Reverend of PCEA, Interviewed on December 17 2018 at PCEA Ayub Kinyua, Eldoret.

Kinyua, C ( 2018). Oral Interview at Nakuru on $13^{\text {th }}$ December

Kombo, D. K., \& Tromp, D. L. (2006). Proposal and Thesis Writing: An Introduction. Nairobi: Paulines Publication Africa.

Lemayan, T. (2018). PCEA Church Elder, Interviewed on December $18^{\text {th }} 2018$ at PCEA PCEAMuruai Church, Laikipia.

Lind, J., Mutahi, P., \&Oosterom, M. (2015). Tangled ties: al-shabaab and political volatility in Kenya (No. IDS Evidence Report; 130). IDS.

Linke, A. M. (2013). The aftermath of an election crisis: Kenyan attitudes and the influence of individual-level and locality violence. Political Geography, 37, 5-17.

Maina, D (2018). Oral Interview at Nakuru on $13^{\text {th }}$ December

Matthew, R. A., Brown, O., \& Jensen, D. (2009). From conflict to peace building: the role of natural resources and the environment (No. 1). UNEP/Earthprint.

Mbugua, K. (2018). PCEA Church Elder, Interviewed on December $18^{\text {th }} 2018$ at PCEA PCEAMuruai Church, Laikipia.

Mokaya, B. M., Oyugi, E. A., Kigen, E. M., Gatumu, H. N., \&Ireri, A. M. (2013). Evaluating the Effectiveness of Three Conflict Resolution Models in Changing Students' Intergroup Expectancies and Attitudes in Kenyatta University (Kenya). Education, 3(3), 178-184.

Mugo, J. (2016). An Analysis of Mediation as a tool in Conflict Resolution in Africa: A Case Study of Mediation Process in South Sudan between December 2013-March 2015 (Doctoral Dissertation, Institute of Diplomacy and International Studies, University of Nairobi, Kenya.

Muibei, D. (2018). PCEA Church Elder, Interviewed on December $17^{\text {th }} 2018$ at PCEA Ayub Kinyua Church, Eldoret.

Munyoroku, J (2018). Oral Interview at Nakuru on $13^{\text {th }}$ December

Mumbi, Z. N. (2013). The Evolution of Elite Manipulation of Ethnicity and Electoralviolence in Kenya (18952007): An Emerging Security Challenge for Eastern and Central Africa. Nairobi: Truford.

Munyoroku, J. (2018). Reverend of PCEA, Interviewed on October $27^{\text {th }} 2018$ at PCEA Saint Margaret Church, Mombasa.

Muranga, S. (2018). Reverend of PCEA, Interviewed on December $15^{\text {th }} 2018$ at PCEA Saint Ninian's Church, Nakuru. 
Muraguri, S. (2018). Reverend of PCEA, Interviewed on December $18^{\text {th }} 2018$ at PCEA PCEAMuruai Church, Laikipia.

Murithi, J. (2018). Reverend of PCEA, Interviewed on December 17 2018 at PCEA Ayub Kinyua, Eldoret.

Musau, B. (2009). Ethnic conflicts and transition to democracy in Africa: recurrence of ethnic conflicts in Kenya (1991-2008). Südwind-Verlag.

Mutegi, F. M. (2008). Influence of Social-Cultural Diversity on Employees' attitude Towards Performance.

Muthomi, F. (2018). Reverend of PCEA, Interviewed on October $27^{\text {th }} 2018$ at PCEA Saint Margaret Church, Mombasa.

Mwandoe, T. (2018). Reverend of PCEA, Interviewed on October 27 2018 at PCEA Saint Margaret Church, Mombasa.

Mwangi, J. (2018). Reverend of PCEA, Interviewed on December $15^{\text {th }} 2018$ at PCEA Saint Ninian's Church, Nakuru.

Mwaniki, T. W. (2007). Peace Building \& Conflict Management in Kenya: Joint Case Study of Northrift Region of Kenya (Vol. 15). Paulines Publications Africa.

Njoroge, J. (2018). Reverend of PCEA, Interviewed on December $18^{\text {th }} 2018$ at PCEA Muruai Church, Laikipia.

Nthambiri, T. (2018). Reverend of PCEA, Interviewed on December $15^{\text {th }} 2018$ at PCEA Saint Ninian's Church, Nakuru.

Ntondwe, W. (2018). PCEA Church Elder, Interviewed on October $27^{\text {th }} 2018$ at PCEA Saint Margaret Church, Mombasa.

Obadia, P. (2018). PCEA Church Elder, Interviewed on December $18^{\text {th }} 2018$ at PCEA PCEAMuruai Church, Laikipia.

Paul II, P. J. (1979). Sign of Contradiction. London: Hyperion Books.

PCEA Records. (2015). Report on the Status of Presbyteries in PCEA in Kenya. Nairobi: Jitegemea Press.

PCEA Records (2018). Report on the Status of Presbyteries in PCEA in Kenya. Nairobi: Jitegemea Press.

Report of the Truth, Justice and Reconciliation Commission (2013). Nairobi: TJRC

Rirei, M (2018). Oral Interview at Eldoret on $17^{\text {th }}$ December 2018

Ruto, C. (2018). Reverend of PCEA, Interviewed on December 17 2018 at PCEA Ayub Kinyua, Eldoret.

Sang, R. (2018). Reverend of PCEA, Interviewed on December 17 2018 at PCEA Ayub Kinyua, Eldoret.

Sawe, P. (2018). Reverend of PCEA, Interviewed on December 17 $7^{\text {th }} 2018$ at PCEA Ayub Kinyua, Eldoret.

Schilling, J., Opiyo, F. E., \&Scheffran, J. (2012). Raiding pastoral livelihoods: motives and effects of violent conflict in north-western Kenya. Pastoralism: Research, Policy and Practice, 2(1), 25.

Schumacher, S., \&Mcmillan, J. (2006). Research in Education Evidence-Based Inquiry. Boston: Pearson Education.

Scott-Villiers, P., Ondicho, T., Lubaale, G., Ndung'u, D., Kabala, N., \&Oosterom, M. (2014). Roots and Routes of Political Violence in Kenya's Civil and Political Society: A Case Study of Marsabit County (No. IDS Evidence Report; 71). IDS.

Sedgwick, M. (2010). The Concept of Radicalization as A Source of Confusion. Terrorism and Political Violence, 22(4), 479-494.

Sehrawat, R., \& Sharma, R. (2018). Promoting International Collaborative Academic Practices Using Social Media Tools. Advance and Innovative Research, 124.

Sharamo, R. (2014). The politics of pastoral violence: a case study of Isiolo County, Northern Kenya. Future Agricultures Consortium Working Paper, 95.

Simiyu, R. R. (2008). Militianisation of resource conflicts: the case of land-based conflict in the Mount Elgon region of western Kenya. Institute for Security Studies Monographs, 2008(152), 80.

Smith, D. (2004). Towards a Strategic Framework for Peace-Building: Getting Their Act Together, overview report of the Joint Utstein Study of Peace-Building, Royal Norwegian Ministry of Foreign Affairs. Accessed on $2^{\text {nd }}$ February, 2019 from http//www.prio.no/files/44563.

Smock, D. R. (2010). “Conclusion.” In Religion and Spirituality: Religious Contributions to Peacemaking, edited by David Smock, 43-48. New York, NY: Nova Science Publishers.

Soi, R. \&Onyancha, B. (2016). Search for Participatory Leadership in Management of Church Resources in the Roman Catholic Church with Particular Reference to Kaplong Parish of Bomet County, Kenya. International Journal of Innovative Research and Development, 5(13).

Stovel, L., \&Valiñas, M. (2010). Restorative Justice after Mass Violence: Opportunities and risks for children and youth. UN.

Stovel, L., \&Valiñas, M. (2010). Restorative Justice after Mass Violence: Opportunities and risks for children and youth. UN. 
Streets, F.J., 2014, 'Relational social work and religious diversity', in J.B. Rosenberger (ed.), Relational Social Work Practice with Diverse Populations, pp. 67-78, Springer, New York.

Wahome, M. 2018). PCEA Church Elder, Interviewed on December $18^{\text {th }} 2018$ at PCEA PCEAMuruai Church, Laikipia

Waithaka, J. (2018). Reverend of PCEA, Interviewed on December $15^{\text {th }} 2018$ at PCEA Saint Ninian's Church, Nakuru.

Wamani, W. (2018). PCEA Church Elder, Interviewed on December $17^{\text {th }} 2018$ at PCEA Ayub Kinyua, Eldoret.

Wane, E. G., Mwaura, C., Hailu, S., Kopfmueller, S., Bond, D., Engel, U., \& Porto, J. G. (2010). The Continental Early Warning System: Methodology and Approach. Africa's New Peace and Security Architecture.Farnham. Ashgate Publishing Limited.

Warutere, P. (2018). Reverend of PCEA, Interviewed on December $18^{\text {th }} 2018$ at PCEA PCEAMuruai Church, Laikipia.

Wasserman, H., \&Mwende, M. J. (2014). The Tension Between Ethics and Ethnicity: Examining Journalists' Ethical Decision-Making at the Nation Media Group in Kenya. Journal of African Media Studies, 6(2), 165-179. 